\title{
Legal Standing of Apprentice Midwives as Health Personnels in Providing Health Services A Case Study at Health Center II of Melaya, Jembrana, Bali
}

\author{
Kedudukan Hukum Bidan Magang Sebagai Tenaga Kesehatan \\ dalam Memberikan Pelayanan Kesehatan \\ (Studi Kasus Di Puskesmas II Melaya, Jembrana, Bali) \\ Tias Rizki Ferlina, Trihoni Nalesti Dewi, Hadi Sulistyanto \\ email: tiasrizkiferlina@gmail.com
}

Health Law Master Program, Soegijapranata Catholic University of Semarang

\begin{abstract}
Jembrana Jembrana District was one of the Districts implementing health services through midwife apprenticeship program. One of the requirements of what so-called apprentice midwives was they who had graduated from formal education of Diploma III and Diploma IV grades. The apprentice midwives appointment was conducted by the Head of the District Health Office and it was for two-year period. During the period of apprenticeship the midwives were under the guidance of Civil Servant or Contract midwives. This study used socio-legal approach and its specification was explicative in order to view, assess and explain the relationships between the legal standing of apprentice midwife within Indonesian legal system and the legal issues appearing about the job accomplishment of the apprentice midwives. The data consisted of primary and secondary data that were then qualitatively analyzed. The results of the study showed that there was no regulation regarding the legal standing of the apprentice midwives and this made the midwives legally unprotected. Midwife apprenticeship had been carried out since 2011 but it was not a regional policy, because there was no any Regional Regulation giving a basic arrangement on it. The Head of District Health Office appointed apprentice midwives without any authority base that was granted by any legislation nor without a discretionary authority by the Regent of Jembrana. The Internship Agreement explained that the apprentice midwifes should be willing and able not to get $a$ service fee and not demand to be appointed as Civil Servants or Contract workers of the Health Office of Jembrana District, and the Health Office of Jembrana District did not issue maternity and child birth leave letters for apprentice midwives. Besides, for the midwives as health personnels the content of the Apprenticeship Agreement was therefore contrary to the Human Rights principles because there was no basic regulations of midwife apprenticeship, the fulfillment of midwife's rights and, from its establishment point of view, the agreement was invalid. Therefore, the apprenticeship agreement could be concluded as null and void.
\end{abstract}

Keywords: legal standing, apprenticeship midwife, authority, agreement 


\section{PENDAHULUAN}

Bidan sebagai salah satu unsur tenaga kesehatan dalam sistem pelayanan kesehatan memiliki peran dalam mengurangi angka kematian bayi dan ibu yang melahirkan, baik dalam proses persalinan maupun dalam memberikan penyuluhan atau panduan bagi ibu hamil. Melihat besarnya peranan bidan tersebut, maka haruslah ada pembatasan yang jelas mengenai hak dan kewajiban bidan dalam pelaksanaan tugas dan kewenangan bidan tersebut. ${ }^{1}$

Kedudukan seorang bidan sebagai salah satu tenaga kesehatan merupakan bagian tidak terpisahkan dari pelayanan kesehatan yang mengarah pada mewujudkan kesejahteraan keluarga dalam rangka tercapainya keluarga yang sehat dan berkualitas. ${ }^{2}$ Bidan sendiri diartikan sebagai seorang perempuan yang lulus dari pendidikan bidan yang telah teregistrasi sesuai dengan ketentuan peraturan perundang-undangan. ${ }^{3}$ Sedangkan kedudukan bidan diartikan sebagai status atau tingkatan bidan dalam menjalankan profesinya di pelayanan kesehatan. ${ }^{4}$ Pelayanan kebidanan diberikan sesuai dengan kewenangannya yang bertujuan meningkatkan kesehatan ibu dan anak dalam rangka tercapainya keluarga berkualitas, bahagia, dan sejahtera. Tindakan yang dilakukan oleh profesi kebidanan didasari oleh kompetensi dan evidence based 5 serta diperkuat oleh landasan hukum yang mengatur profesi tersebut. ${ }^{6}$ Seorang bidan memiliki kewenangan dan kemandirian untuk bertindak secara profesional dengan ilmu pengetahuan dan keterampilan yang dimiliki berdasarkan standar profesi kebidanan. ${ }^{7}$

Tugas pokok tenaga kesehatan bidan diantaranya melaksanakan asuhan kebidanan meliputi asuhan kepada ibu hamil, bersalin, bayi baru lahir, dan Keluarga Berencana yang selanjutnya disingkat dengan (KB) secara komprehensif. Tugas pokok bidan yang dikerjakan mencerminkan kompetensi yang dimiliki oleh bidan tersebut. Bidan harus melakukan tugasnya dengan penuh rasa tanggung jawab agar terhindar dari kesalahan dalam melakukan tugas pokok bidan. ${ }^{8}$

Dewasa ini, tuntutan dunia kerja yang semakin tinggi mengakibatkan proses pemagangan menjadi sangat penting dan dibutuhkan ke depannya, tidak terkecuali bagi tenaga kesehatan bidan. Permasalahan magang telah diatur dalam Pasal 21 sampai dengan Pasal 30 Undang-Undang Republik Indonesia Nomor 13 Tahun 2003 tentang Ketenagakerjaan. Dan lebih spesifik diatur dalam Peraturan Menteri Tenaga Kerja Dan Transmigrasi Republik Indonesia Nomor 22 Tahun 2009 yang menjelaskan bahwa pemagangan merupakan sebuah bagian dari sistem pelatihan kerja yang diselenggarakan secara terpadu antara pelatihan di sebuah lembaga pelatihan dengan bekerja secara langsung dibawah bimbingan dan

\footnotetext{
${ }^{1}$ Marmi, 2014, Etika Profesi Bidan, Yogyakarta: Pustaka Pelajar, hal. 39

2 Endang Purwoastuti dan Elisabeth Siwi Walyani, 2014, Konsep Kebidanan, Yogyakarta: Pustaka Baru Press, hal. 6

3 Peraturan Menteri Kesehatan Republik Indonesia Nomor 28 Tahun 2017tentang Izin Dan Penyelenggaraan Praktik Bidan

${ }^{4}$ Marwan, M, dan Jimmy. P, 2009, Kamus Hukum: Dictionary Of Law Complete Edition, Jakarta: Reality Publisher, hal. 337

5 Evidence based artinya berdasarkan bukti, tidak lagi berdasarkan pengalaman atau kebiasaan semata. Bukti inipun tidak sekedar bukti, namun bukti ilmiah terkini yang bisa dipertanggung jawabkan.

${ }^{6}$ Marmi, Op. Cit., hal. 47

7 Endang Purwoastuti dan Elisabeth Siwi Walyani, 2015, Mutu Pelayanan Kesehatan \& Kebidanan, Yogyakarta:

Pustaka Baru Press, hal. 1

${ }^{8}$ Endang Purwoastuti dan Elisabeth Siwi Walyani, Konsep Kebidanan, Op. Cit., hal. 50
} 
pengawasan instruktur atau pekerja yang lebih berpengalaman dalam proses produksi barang dan/atau jasa dalam rangka menguasai keterampilan atau keahlian tertentu. ${ }^{9}$

Kegiatan magang merupakan upaya untuk melakukan alih pengetahuan, keterampilan, dan sikap dengan berbasis tempat kerja. Dalam kegiatan magang, seorang bidan magang memiliki kesempatan untuk mengaplikasikan ilmu yang telah dipelajari di bangku kuliah dan mempelajari lebih detail tentang standar kerja yang profesional. Pengalaman ini kemudian menjadi bekal dalam menjalani jenjang karir yang sesungguhnya. Secara umum, diadakannya pemagangan bidan di puskesmas bertujuan untuk meningkatkan kemampuan tim puskesmas dalam memberikan pertolongan persalinan dengan fokus pada kesiapan menghadapi emergensi maternal dan neonatal, baik dari sisi pengetahuan, keterampilan dan perubahan perilaku, termasuk melakukan stabilisasi sebelum melakukan rujukan. ${ }^{10}$ Seorang bidan magang diartikan sebagai bidan yang bekerja dengan pendekatan berbasis tempat kerja yang memungkinkan bidan magang tersebut bekerja sesuai dengan kualifikasi kompetensinya berdasarkan pendidikan yang diakui dalam sebuah pengalihan pengetahuan dan keterampilan di fasilitas kesehatan. ${ }^{11}$

Hingga bulan September 2018 Puskesmas II Melaya memiliki bidan magang sebanyak 8 orang. Dalam satu tim jaga terdapat 3 orang bidan yang terdiri dari bidan Pegawai Negeri Sipil yang selanjutnya disingkat dengan (PNS), bidan kontrak, dan bidan magang. Meskipun jumlah bidan magang sebanyak 8 orang, namun apabila dalam kondisi pasien sedang banyak, satu tim jaga merasa kewalahan dan mempengaruhi pelayanan yang diberikan kepada pasien. Serta kurangnya komunikasi bidan magang pada saat melakukan tindakan terhadap pasien yang menyebabkan kurangnya rasa percaya pasien pada bidan magang tersebut. Bidan magang di Puskesmas II Melaya pernah melakukan kesalahan dalam membedakan selang infus makro dan mikro. Meskipun selang infus tersebut belum dipasang kepada pasien, namun hal ini merupakan kesalahan dalam sebuah tindakan kesehatan yang bisa merugikan pasien dari segi kesehatan dan finansial.

Studi pendahuluan yang dilakukan di Puskesmas II Melaya Kabupaten Jembrana di Provinsi Bali, pada kenyataannya bidan magang yang bekerja di Puskesmas II Melaya bukan seorang mahasiswa kebidanan, namun seorang lulusan bidan jenjang Diploma III atau Diploma IV yang memasukkan berkas lamaran kerja terlebih dahulu ke Dinas Kesehatan Kabupaten Jembrana. Dalam hal ini maka Dinas Kesehatan Kabupaten Jembrana melalui mekanisme yang ada dapat meyakinkan bahwa puskesmas yang telah ditentukan tersebut membutuhkan bidan magang dan selanjutnya akan dipilih menjadi tempat magang bagi bidan yang telah memasukkan lamaran tersebut. Kemudian dalam penerapannya, bidan magang di Kabupaten Jembrana tidak mendapatkan imbalan jasa dari Dinas Kesehatan.

Penulis merasa tertarik untuk melakukan penelitian di Puskesmas II Melaya dikarenakan letak puskesmas tersebut berada di paling barat dari pulau Bali, yang mana apabila dalam melakukan kegiatan perujukan pasien ke fasilitas kesehatan tingkat selanjutnya membutuhkan waktu yang lama dan melewati medan berupa hutan. Serta pasien yang datang untuk mencari solusi bagi permasalahan kesehatannya tidak hanya masyarakat

\footnotetext{
9 Peraturan Menteri Tenaga Kerja Dan Transmigrasi Republik Indonesia Nomor PER.22/MEN/IX/2009 tentang Penyelenggaraan Pemagangan Di Dalam Negeri

${ }^{10}$ Petunjuk Praktis Magang Di Rumah Sakit Bagi Staff Puskesmas, hal. 5, Online Internet, 24 September 2018, Pukul 19.55 WIB, https://www.scribd.com/document/361192696/magang

${ }^{11} \mathrm{lbid}$, hal. 7
} 
kabupaten Jembrana saja, namun masyarakat kabupaten Buleleng dinilai cukup sering datang ke Puskesmas II Melaya.

Berdasarkan pada uraian pembahasan diatas penulis merasa tertarik untuk melakukan penelitan hukum kesehatan dengan judul "Kedudukan Hukum Bidan Magang Sebagai Tenaga Kesehatan Dalam Memberikan Pelayanan Kesehatan Studi Kasus Di Puskesmas II Melaya, Jembrana, Bali."

\section{PERUMUSAN MASALAH}

Berdasarkan uraian di atas, maka perumusan masalah yang akan diambil dalam penulisan ini adalah sebagai berikut:

1. Bagaimanakah kedudukan bidan magang sebagai tenaga kesehatan dalam memberikan pelayanan kesehatan dalam ketentuan hukum di Indonesia?

2. Bagaimanakah pelaksanaan tugas dan kewenangan bidan magang sebagai tenaga kesehatan dalam memberikan pelayanan kesehatan di Puskesmas II Melaya, Jembrana, Bali?

3. Persoalan hukum apakah yang muncul dalam pelaksanaan tugas bidan magang sebagai tenaga kesehatan dalam memberikan pelayanan kesehatan?

\section{METODE PENELITIAN}

\section{Metode Pendekatan}

Metode pendekatan yang digunakan dalam penelitian ini adalah yuridis sosiologis yaitu pendekatan dengan melihat suatu kenyataan hukum di dalam masyarakat. Dimana dalam pendekatan ini dapat membahas aspek yuridisnya (aspek hukum) dan sekaligus dapat membahas aspek sosialnya yang melingkupi gejala hukum tertentu. ${ }^{12}$ Aspek yuridis dalam penelitian ini adalah seperangkat peraturan yang berkaitan dengan kedudukan hukum bidan magang sebagai tenaga kesehatan. Dari aspek sosiologisnya terlebih dahulu mengkaji peraturan perundang-undangan dan kepustakaan yang berkaitan dengan kedudukan hukum bidan magang dan selanjutnya melakukan penelitian dengan wawancara kepada responden dan narasumber menggunakan pedoman wawancara.

\section{Spesifikasi Penelitian}

Spesifikasi penelitian ini menggunakan metode eksplikatif yaitu penelitian yang bermaksud melihat dua gejala untuk menilai hubungan antara peraturan hukum dengan penerapannya di lapangan dan untuk menemukan penjelasan mengapa suatu kejadian atau gejala dapat terjadi. ${ }^{13}$ Dalam hal ini peraturan hukumnya berupa peraturan yang berkaitan dengan kedudukan hukum bidan magang sebagai tenaga kesehatan dalam ketentuan hukum di Indonesia, serta menghubungkan dengan persoalan hukum yang muncul dalam pelaksanaan tugas bidan magang sebagai tenaga kesehatan.

\footnotetext{
${ }_{12}$ Zainudin Ali, 2016, Metode Penelitian Hukum, Jakarta: Sinar Grafika, hal. 105

13 Sugiyono, 2011, Statistika Untuk Penelitian, Bandung: Alfabeta, hal. 9
} 


\section{Jenis Data}

Jenis data yang digunakan adalah data primer dan data sekunder. Data primer diperoleh langsung dari wawancara dengan responden yaitu bidan magang dan bidan PNS di Puskesmas II Melaya, serta wawancara dengan narasumber diantaranya Ahli Hukum dari Universitas Katolik Soegijapranata Semarang, Kepala Puskesmas II Melaya, Ketua Ikatan Bidan Indonesia yang selanjutnya disingkat dengan (IBI) cabang Kabupaten Jembrana, Kepala Dinas Kesehatan Kabupaten Jembrana, dan Kepala Badan Kepegawaian Dan Pengembangan Sumber Daya Manusia yang selanjutnya disingkat dengan (BKPSDM) Kabupaten Jembrana. Kemudian data sekunder diantaranya bahan hukum primer, bahan hukum sekunder, dan bahan hukum tersier. Bahan hukum primer menggunakan peraturan perundang-undangan terkait penelitian. Lalu bahan hukum sekunder menggunakan buku-buku, tesis, jurnal, dan bahan pustaka lainnya yang memiliki relevansi dengan penelitian. Terakhir yaitu bahan hukum tersier berupa kamus, artikel, dan data valid yang bersumber dari internet sesuai dengan penelitian ini.

\section{Metode Pengumpulan Data}

Metode pengumpulan data menggunakan metode penelitian kepustakaan dan metode penelitian lapangan. ${ }^{14}$ Metode penelitian kepustakaan bersumber dari buku-buku milik pribadi dan perpustakaan Universitas Katolik Soegijapranata Semarang, jurnal, artikel, serta peraturan perundang-undangan yang terkait dengan permasalahan pada penelitian. Kemudian metode penelitian lapangan didapat dari wawancara dengan responden dan narasumber dengan menggunakan pedoma wawancara. ${ }^{15}$

\section{Metode Analisis}

Metode analisis yang digunakan adalah analisis kualitatif yaitu mendefinisikan suatu penelusuran untuk mengeksplorasi dan memahami suatu gejala sentral atau terpusat. ${ }^{16}$ Untuk mengetahui gejala sentral tersebut peneliti melakukan wawancara dengan responden dan narasumber menggunakan pedoman wawancara. Hasil wawancara dikumpulkan dan diolah dalam bentuk tabel hasil wawancara, kemudian dianalisis menggunakan matriks perundang-undangan. Kemudian diuraikan secara narasi dengan memberikan pandangan teoritis, serta membuat perenungan pribadi dan dijabarkan dalam bentuk laporan tertulis tanpa ketentuan baku tentang struktur dan bentuk laporan hasil penelitian kualitatif. ${ }^{17}$

\section{PEMBAHASAN}

Kedudukan Bidan Magang Sebagai Tenaga Kesehatan Dalam Memberikan Pelayanan Kesehatan Dalam Ketentuan Hukum Di Indonesia

Seorang tenaga kesehatan bidan memiliki peranan penting dalam menjalankan progam pemerintah di Indonesia khususnya dalam bidang pelayanan kebidanan. Untuk meningkatkan cakupan pertolongan oleh tenaga kesehatan, banyaknya lulusan kebidanan, serta mengurangi pengangguran lulusan kebidanan di Kabupaten Jembrana, maka hasil

\footnotetext{
14 Zainudin Ali, Op. Cit., hal. 107

15 Burhan Ashshofa, 2004, Metode Penelitian Hukum, Jakarta: Rineka Cipta, hal. 59

${ }^{16}$ J. R. Raco, 2010, Metode Penelitian Kualitatif Jenis, Karakter Dan Keunggulannya, Jakarta: PT Gramedia

Widiasarana Indonesia, hal. 7

17 Julia Brannen, 2004, Memadu Metode Penelitian Kualitatif \& Kuantitatif, Yogyakarta: Pustaka Pelajar, hal. 47
} 
wawancara dengan IBI Jembrana ${ }^{18}$ menyatakan bahwa bidan membutuhkan kegiatan pemagangan. Kemudian IBI Jembrana mengajukan perihal tersebut kepada Kepala Dinas Kesehatan Jembrana supaya mengadakan kegiatan pemagangan untuk bidan selama 2 tahun di puskesmas atau magang di Bidan Praktik Mandiri. Pemagangan bidan tersebut bertujuan untuk memberikan pengalaman kepada lulusan bidan, sebagai syarat memproses SIPB, dan mendapatkan izin untuk membuka Bidan Praktik Mandiri.

Menurut hasil wawancara dengan Kepala Dinas Kesehatan Jembrana ${ }^{19}$ selaku perangkat daerah yang mengurusi bidang kesehatan, maka Dinas Kesehatan ingin melakukan pengayoman dan pembinaan kepada semua profesi kesehatan termasuk bidan. Disamping itu di Kabupaten Jembrana masih membutuhkan tenaga kesehatan bidan dalam rangka menjalankan program kesehatan khususnya peningkatan mutu pelayanan menurunkan Angka Kematian Ibu (AKI) dan Angka Kematian Bayi (AKB). Akhirnya Kepala Dinas Kesehatan Jembrana memberi peluang sesuai dengan kebutuhan analisis beban kerja berdasarkan uraian tugas Kepala Dinas Kesehatan Kabupaten Jembrana yang secara tersirat berbunyi "meningkatkan pembangunan kesehatan dan mengambil langkah-langkah strategis untuk memenuhi kesehatan". Berdasarkan kalimat tersirat tersebut, menurut Kepala Dinas Kesehatan Jembrana telah diberi kewenangan termasuk sumber daya manusia dalam hal ini adalah pengadaan program bidan magang. Lalu peneliti mencocokkan dengan Peraturan Bupati Jembrana Nomor 40 Tahun 2016 tentang Kedudukan, Susunan Organisasi, Tugas Dan Fungsi, Serta Tata Kerja Dinas Kesehatan. Dalam Peraturan Bupati tersebut tidak ada pernyataan yang menjelaskan tentang pemagangan bidan di Kabupaten Jembrana. Serta tidak ada kalimat tersirat yang dimaksud oleh Kepala Dinas Kesehatan Jembrana tersebut. Pemberian istilah "bidan magang" dikarenakan magang memiliki hubungan yang saling menguntungkan antara bidan magang dan Dinas Kesehatan Jembrana.

Pemagangan dibatasi selama 2 tahun sesuai ketentuan yang diinginkan oleh IBI Jembrana kepada Dinas Kesehatan Jembrana. Kemudian setelah 2 tahun diharapkan bidan bisa mengurus Surat ljin Praktik Bidan yang selanjutnya disingkat dengan (SIPB), ijin praktik bidan mandiri, dan tidak lagi magang di puskesmas tersebut. Sehingga jika ada puskesmas yang membutuhkan bidan magang lagi, Dinas Kesehatan Jembrana akan memberikan kesempatan kepada bidan yang belum mempunyai sertifikat magang supaya lulusan bidan di Kabupaten Jembrana tidak menumpuk. Karena penyelenggaraan pemagangan bidan di Kabupaten Jembrana tidak menggunakan anggaran daerah, maka Dinas Kesehatan tidak memberikan imbalan jasa untuk bidan magang. Walaupun demikian, puskesmas di Jembrana adalah puskesmas yang mengelola keuangan bersifat Badan Layanan Umum Daerah (BLUD) dan memiliki pendapatan fungsional yang digunakan untuk Jasa Pelayanan yang selanjutnya disebut (Jaspel) yang dialokasikan untuk sejumlah bidan magang di puskesmas tersebut. Dalam pelaksanaannya, bidan magang melakukan pekerjaan yang seharusnya dilakukan oleh bidan senior, maka bidan magang berada dibawah tanggung jawab bidan senior dan kepala puskesmas. Sehingga bidan magang tidak diperbolehkan mengambil keputusan sendiri dan harus didampingi bidan senior saat melakukan pelayanan kesehatan. Dikarenakan bidan magang hanya kebijakan profesi IBI dan bukan kebijakan daerah, jadi tidak ada Peraturan Bupati yang mengatur tentang bidan magang di Kabupaten Jembrana. Dengan begitu tidak ada landasan hukum tentang bidan magang, maka bidan magang tidak terlindungi secara hukum dan bisa menjadi masalah di pemerintah.

\footnotetext{
${ }^{18} \mathrm{Ni}$ Ketut Warsini, SKM, Ketua IBI Cabang Kabupaten Jembrana, Wawancara Tanggal 12 Februari 2018

19 dr. Putu Suasta, M.Kes, Kepala Dinas Kesehatan Kabupaten Jembrana, Wawancara Tanggal 12 Februari 2018
} 
Pengangkatan bidan magang tidak dilakukan oleh BKPSDM sesuai hasil wawancara dengan Kepala BKPSDM Jembrana ${ }^{20}$, karena tidak ada Peraturan Daerah yang mengatur tentang bidan magang seperti yang tertuang dalam Undang-Undang Nomor 5 Tahun 2014 tentang Aparatur Sipil Negara (ASN) hanya ada PNS dan Pegawai Pemerintah dengan Perjanjian Kerja (PPPK). Selain itu formasi untuk bidan magang bukan dari Kementerian Pendayagunaan Aparatur Sipil Negara Dan Reformasi Birokrasi (KEMENPAN-RB), melainkan dari Dinas Kesehatan Jembrana. Dengan kata lain tidak ada dasar pelimpahan wewenang yang mengatur bahwa BKPSDM bisa melakukan pengangkatan bidan magang. BKPSDM hanya mengawasi secara umum dari segi kepegawaian, absen bidan magang, dan data jumlah bidan magang. Serta apabila bidan magang tidak disiplin dalam bekerja maka BKPSDM akan turun tangan. Namun secara teknis keseluruhan Dinas Kesehatan Jembrana yang melakukan pengangkatan.

\section{Pelaksanaan Tugas Dan Kewenangan Bidan Magang Sebagai Tenaga Kesehatan Dalam Memberikan Pelayanan Kesehatan Di Puskesmas II Melaya, Jembrana, Bali}

Bidan magang di Puskesmas II Melaya merupakan bidan yang telah meyelesaikan pendidikan bidan jenjang Diploma III dan IV, serta telah memiliki Surat Tanda Registrasi Bidan (STRB) yang menunjukkan bahwa bidan tersebut berkompeten. Namun Kepala Dinas Kesehatan tidak mewajibkan bidan magang memiliki SIPB disebabkan persyaratan untuk bisa memiliki SIPB diharuskan magang terlebih dahulu selama 2 tahun dan sewaktu-waktu diperbolehkan mengundurkan diri untuk bekerja di fasilitas kesehatan lain apabila bidan magang tersebut menginginkan.

Data dari Bagian Umum Dinas Kesehatan Jembrana menunjukkan jumlah bidan magang tahun 2017-2018 sebanyak 56 bidan yang tersebar di 8 puskesmas wilayah Kabupaten Jembrana. Hasil penelitian yang didapat dari arsip Tata Usaha Puskesmas II Melaya menunjukkan bahwa secara resmi Puskesmas II Melaya menerima bidan magang dari Dinas Kesehatan Kabupaten Jembrana sejak tahun 2011 dan telah berlangsung sampai dengan saat ini tahun 2018. Dan sekarang jumlah bidan magang di Puskesmas II Melaya sebanyak 8 orang bidan.

Hasil wawancara dengan Kepala Puskesmas II Melaya ${ }^{21}$ mengatakan bahwa sesuai acuan dari akreditasi puskesmas tipe B setiap bidan magang yang baru di Puskesmas II Melaya wajib mengikuti kegiatan credentialing ${ }^{22}$ atau orientasi selama 7 hari yang bertujuan supaya bidan magang mengenal lebih awal tempat kerja yang baru, mengenal pegawai puskesmas, mengenal sesama tenaga kesehatan, mengenal pekerjaannya, dan di ruang mana bidan magang akan bekerja. Selama proses tersebut bidan magang diberi tugas membuat Laporan Credentialing berupa tulisan yang berisi jumlah pasien dan pelayanan kesehatan apa saja yang sudah dilakukan. Kemudian dilakukan penempatan apakah bidan magang tersebut ditempatkan di Ruang Persalinan, Rawat Inap, Unit Gawat Darurat (UGD), Poliklinik Umum, Poliklinik Anak, atau Poliklinik Kesehatan Ibu Dan Anak (KIA) sesuai dengan hasil Laporan Credentialing yang telah dibuat. Tidak hanya bidan magang, tetapi bidan PNS atau Kontrak yang baru ditugaskan di Puskesmas II Melaya oleh Dinas Kesehatan juga wajib mengikuti proses credentialing.

\footnotetext{
${ }^{20}$ Drs. I Made Budiasa, M.Si, Kepala Badan Kepegawaian Dan Pengembangan Sumber Daya Manusia (BKPSDM) Kabupaten Jembrana, Wawancara Tanggal 13 Februari 2018

${ }^{21}$ dr. Riadi Wiranuaba, Kepala Puskesmas II Melaya, Wawancara Tanggal 19 Februari 2018

${ }^{22}$ Credentialing adalah proses evaluasi terhadap tenaga kesehatan untuk menentukan kelayakan pemberian kewenangan klinis
} 
Dalam menjalankan pekerjaannya, menurut hasil wawancara dengan bidan PNS Puskesmas II Melaya ${ }^{23}$ menyatakan bidan magang di Puskesmas II Melaya diizinkan untuk melakukan pelayanan kebidanan mulai dari Antenatal Care (ANC), persalinan, pemeriksaan Inspeksi Visual Asam Asetat (IVA), dan pemasangan maupun pencabutan KB. Kegiatan pelayanan kebidanan yang dilakukan oleh bidan magang tersebut memiliki syarat khusus yaitu harus didampingi oleh bidan PNS atau Kontrak karena bidan magang melakukan pekerjaan dari bidan senior dan bidan magang tidak memiliki payung hukum yang secara khusus melindungi. Serta bidan magang tidak diizinkan memegang program kerja puskesmas secara langsung, hanya bidan PNS dan Kontrak yang diizinkan dan diperbolehkan. Hal serupa dijelaskan oleh bidan magang di Puskesmas II Melaya ${ }^{24}$ yang mengatakan bahwa semua pelayanan kebidanan boleh dilakukan dengan pendampingan dari senior karena bidan magang tidak memiliki payung hukum yang melindungi.

Selain tidak memiliki peraturan yang secara khusus mengatur tentang bidan magang, di sisi lain bidan magang juga tidak diberikan imbalan jasa selama menjalankan pemagangan. Serta bidan magang harus bersedia dan sanggup tidak menuntut pengangkatan sebagai PNS atau Kontrak pada Dinas Kesehatan Kabupaten Jembrana sesuai dengan isi Surat Perjanjian Magang. Namun Kepala Puskesmas II Melaya berusaha mengalokasikan dari Jasa Pelayanan untuk diberian kepada bidan magang sebab telah berjasa kepada puskesmas. Kemudian didapatkan dari hasil wawancara dengan bidan magang bahwa pembagian Jasa Pelayanan untuk tiap bidan mendapatkan \pm Rp.300.000,- dan diberikan setiap 3 bulan sekali. Selain itu, bidan magang tidak mendapatkan cuti pada saat hamil dan melahirkan sesuai keterangan dari Kepala Dinas Kesehatan Jembrana yang tidak mengeluarkan ijin cuti untuk bidan magang. Namun atas dasar kemanusiaan, Kepala Puskesmas II Melaya memberikan kebijakan ijin istirahat selama 3 hari dan untuk ijin yang terlalu lama akan dikoordinasi dengan Dinas Kesehatan, kemudian keputusan dilakukan oleh Dinas Kesehatan.

Untuk saat ini Kepala Puskesmas II Melaya belum pernah melakukan evaluasi untuk bidan magang yang telah melewati pemagangan selama 2 tahun. Namun Kepala Dinas Kesehatan Jembrana menjelaskan bahwa setiap tahun ada evaluasi yang dilakukan terhadap seluruh tenaga kesehatan baik PNS, Kontrak, dan magang melalui Kepala Puskesmas. Hal tersebut bertujuan untuk menentukan apakah pemagangan diperpanjang atau tidak meskipun diberi waktu selama 2 tahun. Apabila dalam satu tahun kinerja bidan magang tidak baik maka akan dikeluarkan oleh Kepala Dinas Kesehatan Kabupaten Jembrana.

Sebagai salah satu intansi pemerintah yang memiliki dasar pelayanan kepada masyarakat, maka Kepala Puskesmas II Melaya berterima kasih kepada Dinas Kesehatan yang telah memberikan tenaga bidan magang sehingga puskesmas banyak berbuat untuk memajukan kesehatan di Jembrana dan khususnya di Kelurahan Gilimanuk. Saat ini Kabupaten Jembrana memiliki selogan "Demi Jembrana" supaya semua tindakan kebidanan dilakukan oleh tenaga bidan dan tidak dilakukan oleh tenaga non kesehatan. Dengan adanya bidan magang di Puskesmas II Melaya sangat membantu manajemen puskesmas untuk melakukan tindakan secara optimal.

\section{Persoalan Hukum Yang Muncul Dalam Pelaksanaan Tugas Bidan Magang Sebagai Tenaga Kesehatan Dalam Memberikan Pelayanan Kesehatan}

\footnotetext{
23 Ni Ketut Sutami, Bidan PNS Puskesmas II Melaya, Wawancara Tanggal 19 Februari 2018

24 Galuh Pramita, Amd.Keb, Bidan Magang Puskesmas II Melaya, Wawancara Tanggal 19 Februari 2018
} 
Menurut hasil wawancara dengan Ketua IBI, karena terlalu banyak bidan di Kabupaten Jembrana, maka pemagangan bidan selama 2 tahun di Kabupaten Jembrana diawali oleh permintaan IBI Jembrana kepada Kepala Dinas Kesehatan Jembrana. Ketua IBI Jembrana menyatakan bahwa pemagangan bidan selama 2 tahun tidak memiliki surat khusus dari IBI Provinsi Bali, karena keputusan tersebut hanya berdasarkan hasil rapat.

Seperti diketahui pengangkatan bidan magang secara teknis dilakukan langsung oleh Dinas Kesehatan Jembrana. Kepala Dinas Kesehatan Kabupaten Jembrana mengangkat bidan untuk melakukan pemagangan selama dua tahun dan mengeluarkan Surat Perjanjian Magang yang ditandatangani oleh bidan magang dan Kepala Dinas Kesehatan, yang kemudian diberi materai 6000. Dalam Pasal 8 Peraturan Bupati Jembrana Nomor 40 Tahun 2016 tentang Kedudukan, Susunan Organisasi, Tugas Dan Fungsi, Serta Tata Kerja Dinas Kesehatan tidak terdapat poin yang menyatakan bahwa Kepala Dinas dapat mengangkat bidan magang di wilayah Kabupaten Jembrana. Dengan begitu Bupati Jembrana tidak mendistribusikan kewenangan kepada Kepala Dinas Kesehatan atau dengan kata lain Kepala Dinas Kesehatan Jembrana tidak memiliki kewenangan delegatif. Terlepas dari tidak adanya Peraturan Bupati Jembrana yang mengatur Kepala Dinas Kesehatan dapat mengangkat bidan magang, selain itu di dalam Undang-Undang Nomor 36 Tahun 2009 tentang Kesehatan, Undang-undang Nomor 36 Tahun 2014 tentang Tenaga Kesehatan, Peraturan Menteri Kesehatan Nomor 28 Tahun 2017 tentang Izin Dan Penyelenggaraan Praktik Bidan, serta Rancangan Undang-Undang tentang Kebidanan (Midwifery) tidak ada yang menjelaskan tentang pemagangan untuk seorang bidan yang sudah lulus.

Kemudian Pasal 1320 Kitab Undang-Undang Hukum Perdata menjelaskan syarat sahnya suatu perjanjian, diantaranya: 25

1. adanya kata sepakat bagi mereka yang mengikatkan dirinya;

2. kecakapan para pihak untuk membuat suatu perikatan;

3. suatu hal tertentu;

4. suatu sebab (causa) yang halal.

Dalam syarat sahnya perjanjian diatas nomor 1 dan 2 merupakan syarat subyektif atau subjek perjanjian. Kemudian nomor 3 dan 4 merupakan syarat obyektif atau objek perjanjian. Yang dimaksud persyaratan nomor 1 adalah para pihak yang mengikatkan diri, dalam hal ini yaitu Kepala Dinas Kesehatan dan bidan magang. Kemudian yang dimaksud persyaratan nomor 2 yaitu kecakapan dalam hal ini merupakan kewenangan Kepala Dinas Kesehatan Jembrana.

Berdasarkan hasil wawancara dengan Ahli Hukum, karena dalam Peraturan Bupati Jembrana Nomor 40 Tahun 2016 tentang Kedudukan, Susunan Organisasi, Tugas Dan Fungsi, Serta Tata Kerja Dinas Kesehatan tidak ada pernyataan bahwa Kepala Dinas Kesehatan Jembrana memiliki kewenangan atau kemampuan untuk mengangkat bidan magang, maka dengan demikian dapat dikatakan bahwa Kepala Dinas Kesehatan tidak memiliki kecakapan untuk melakukan perbuatan hukum, dalam hal ini adalah membuat Surat Perjanjian Magang. Maka Kepala Dinas Kesehatan Jembrana tidak memenuhi syarat subyektif nomor 2 dari Pasal 1320 Kitab Undang-Undang Hukum Perdata.

25 Pasal 1320 Kitab Undang-Undang Hukum Perdata 
Kemudian jika dilihat dari isi Surat Perjanjian Magang yang dibuat oleh Kepala Dinas Kesehatan Jembrana yang berbunyi sebagai berikut: ${ }^{26}$

1. PIHAK PERTAMA memberikan ijin PIHAK KEDUA sebagai tenaga magang pada UPT Puskesmas I Negara untuk mendapatkan pengalaman kerja maksimal 2 (dua) tahun dari tanggal 16 Januari 2017 s/d 16 Januari 2019 dengan mendapat bimbingan teknis dari pegawai senior.

2. PIHAK KEDUA bersedia dan sanggup tidak mendapat honor atau Gaji dari pihak PERTAMA selama mengikuti pemagangan.

3. PIHAK KEDUA bersedia dan sanggup tidak menuntut pengangkatan sebagai CPNS atau pun tenaga out sourching/kontrak pada PIHAK PERTAMA

4. PIHAK KEDUA berkewajiban mematuhi peraturan, etika dan norma yang berlaku di tempat kerja

5. PIHAK KEDUA diberhentikan secara sepihak oleh PIHAK PERTAMA, apabila mencemarkan nama baik institusi dan melanggar etika propesi

6. PIHAK KEDUA dapat memberhentikan diri sebagai tenaga magang sebelum masa berakhir selesai dengan di berikan surat pengalaman kerja oleh PIHAK PERTAMA

Dalam Surat Perjanjian Magang diatas hanya memuat kewajiban bidan magang, namun hakhak bidan yaitu berhak mendapat imbalan jasa dan berhak memperoleh perlindungan hukum sesuai peraturan perundang-undangan yang berlaku tidak disebutkan. Karena pembuatan Surat Perjanjian Magang bertentangan dengan Undang-Undang, ketertiban umum, atau kesusilaan, serta melanggar syarat obyektif sahnya perjanjian sebagaimana yang diatur dalam Pasal 1320 Nomor 3 dan 4 Kitab Undang-Undang Hukum Perdata, maka perjanjian tersebut batal demi hukum (null and void) atau perjanjian yang sejak semula sudah batal.

Hak yang harus diperoleh bidan diantaranya tertuang dalam Pasal 29 Peraturan Menteri Kesehatan Republik Indonesia Nomor 28 Tahun 2017 tentang Izin Dan Penyelenggaraan Praktik Bidan, Pasal 57 Undang-Undang Republik Indonesia Nomor 36 Tahun 2014 tentang Tenaga Kesehatan, dan Pasal 61 Ayat (1) Rancangan Undang-Undang Republik Indonesia Tentang Kebidanan (Midwifery) yang menyatakan bahwa bidan memiliki hak untuk memperoleh perlindungan hukum dan imbalan jasa. Namun dalam Surat Perjanjian Magang tidak mencantumkan hak-hak bidan tersebut.

Jika dikaitkan dengan Hak Asasi Manusia yang selanjutnya disingkat dengan (HAM) bagi profesi tenaga kesehatan bidan yang tertuang dalam Pasal 3 Ayat (2) Undang-Undang Nomor 39 Tahun 1999 tentang Hak Asasi Manusia yang berbunyi: ${ }^{27}$

Setiap orang berhak atas pengakuan, jaminan, perlindungan dan perlakuan hukum yang adil serta mendapat kepastian hukum dan perlakuan yang sama di depan hukum.

Kemudian pada Pasal 38 Ayat (3) Undang-Undang Nomor 39 Tahun 1999 tentang Hak Asasi Manusia yang berbunyi: ${ }^{28}$

\footnotetext{
${ }^{26}$ Surat Perjanjian Magang Nomor 800/003/MGG/Diskes/2017

27 Pasal 3 Ayat (2) Undang-Undang Nomor 39 Tahun 1999 tentang Hak Asasi Manusia

28 Pasal 38 Ayat (3) Undang-Undang Nomor 39 Tahun 1999 tentang Hak Asasi Manusia
} 
Setiap orang, baik pria maupun wanita yang melakukan pekerjaan yang sama, sebanding, setara atau serupa, berhak atas upah serta syarat-syarat perjanjian kerja yang sama.

Dalam dua pasal tentang HAM yang disebutkan diatas memperlihatkan bahwa seorang bidan memiliki hak untuk memperoleh perlindungan hukum dan mendapat upah sebagai imbalan jasa dari pekerjaan yang dilakukan. Namun realitanya bidan magang di Kabupaten Jembrana tidak mendapatkan haknya yaitu tidak memperoleh perlindungan hukum dan tidak mendapat imbalan jasa sesuai dengan isi Surat Perjanjian Magang. Maka konten Surat Perjanjian Magang yang dibuat oleh Dinas Kesehatan Kabupaten Jembrana dapat dikatakan cacat hukum karena melanggar HAM, karena bertentangan dengan Pasal 3 Ayat (2) dan Pasal 38 Ayat (3) Undang-Undang Nomor 39 Tahun 1999 tentang Hak Asasi Manusia. Serta Kepala Dinas Kesehatan menyalahi aturan sebab tidak memiliki kewenangan membuat perjanjian, menandatangani perjanjian, dan mengangkat tenaga bidan magang. Atau dengan kata lain bahwa Kepala Dinas Kesehatan Jembrana melampaui kewenangan yang sudah ada. Serta tidak memberikan hak-hak yang harus diperoleh bidan.

Supaya bidan magang di Kabupaten Jembrana memiliki kedudukan hukum, menurut hasil wawancara dengan Ahli Hukum ${ }^{29}$ menyatakan bahwa Bupati Jembrana perlu membentuk peraturan pelimpahan kewenangan Delegatif atau Mandat kepada Dinas Kesehatan. Pemberian pelimpahan kewenangan Delegatif atau Mandat kepada Dinas Kesehatan dengan pertimbangan bahwa puskesmas di Kabupaten Jembrana membutuhkan bidan magang. Selain itu untuk mempercepat proses penempatan bidan magang dikarenakan Dinas Kesehatan sebagai perangkat daerah yang mengetahui pemetaan bidan magang di Kabupaten Jembrana. Dengan alur yaitu puskesmas di Kabupaten Jembrana memberikan usulan kepada Dinas Kesehatan untuk mengangkat bidan magang.

Bentuk peraturan pelimpahan kewenangan Delegatif atau Mandat bisa berupa Keputusan Bupati atau Peraturan Bupati yang menetapkan tentang Mekanisme Dan Isi beserta bentuk pengangkatannya berupa Perjanjian yang memuat hak-hak bidan magang. Mekanisme Dan Isi dalam Keputusan Bupati atau Peraturan Bupati tersebut harus ada pembatasan waktu berapa lama pemagangan bidan untuk menghindari eksploitasi terhadap bidan magang karena tidak dipenuhinya hak bidan magang, serta bidan magang yang melakukan pemagangan terus-menerus di Kabupaten Jembrana tanpa diberikan imbalan jasa dan tidak memperoleh perlindungan hukum. Maka dari itu, dengan dasar pertimbangan bahwa kualifikasi minimal pendidikan bidan adalah Diploma III Kebidanan selama 3 tahun, maka pemagangan bidan dalam rentang waktu tersebut yaitu 1 tahun atau maksimal 2 tahun dan tidak perlu diperpanjang.

Selanjutnya untuk bentuk pengangkatan yang dimaksud bisa berupa SK Pengangkatan ataupun Perjanjian. Bentuk pengangkatan berupa SK Pengangkatan diperuntukkan bagi PNS, namun bentuk pengangkatan berupa Perjanjian digunakan untuk pegawai tidak tetap atau non PNS yaitu PPPK. Karena bidan magang bukanlah PNS, maka bentuk pengangkatan yang sesuai dengan kondisi tersebut ialah disamakan dengan PPPK yaitu Perjanjian yang memuat hak-hak bidan magang. Dengan adanya peraturan pelimpahan kewenangan Delegatif atau Mandat berupa Keputusan Bupati atau Peraturan Bupati yang menetapkan tentang Mekanisme Dan Isi beserta bentuk pengangkatannya berupa Perjanjian yang

29 Yovita Indrayati, S.H., M.Hum, Ahli Hukum Universitas Katolik Soegijapranata Semarang, Wawancara Tanggal 28 September 2018 
memuat hak-hak bidan magang, maka kedepannya diharapkan bidan magang di Kabupaten Jembrana memiliki kedudukan hukum di muka hukum.

\section{PENUTUP}

\section{KESIMPULAN}

1. Kedudukan Bidan Magang Sebagai Tenaga Kesehatan Dalam Memberikan Pelayanan Kesehatan Dalam Ketentuan Hukum Di Indonesia

Pemagangan bidan berawal dari permohonan IBI Kabupaten Jembrana yang meminta Dinas Kesehatan Kabupaten Jembrana mengadakan pemagangan bidan selama 2 tahun dengan tujuan supaya bidan lulusan baru mendapat pengalaman serta sebagai persyaratan bagi bidan untuk memproses SIPB dan membuka praktik bidan mandiri.

Pengangkatan dilakukan langsung oleh Dinas Kesehatan Jembrana dan tidak dilakukan oleh BKPSDM Jembrana karena tidak ada Peraturan Daerah yang mengatur tentang bidan magang. Selain itu dalam Undang-Undang ASN hanya ada PNS dan tenaga PPPK. Kemudian formasi lowongan bidan magang bukan dari KEMENPAN-RB, melainkan dari Dinas Kesehatan Jembrana yang lebih mengetahui kebutuhan bidan magang di wilayah Kabupaten Jembrana. Dengan kata lain tidak ada dasar pelimpahan wewenang yang mengatur bahwa BKPSDM bisa melakukan pengangkatan bidan magang. BKPSDM hanya mengawasi secara umum.

Proses pengangkatan bidan magang yang dilakukan oleh Dinas Kesehatan Kabupaten Jembrana tidak memiliki dasar peraturan yang jelas. Dalam Undang-Undang Nomor 5 Tahun 2014 tentang Aparatur Sipil Negara hanya menyebutkan pegawai PNS dan PPPK, dan tidak ada pegawai magang. Selain itu dalam peraturan perundang-undangan seperti Undang-Undang Nomor 36 Tahun 2009 tentang Kesehatan, Undang-Undang Nomor 36 Tahun 2014 tentang Tenaga Kesehatan, dan Permenkes Nomor 28 Tahun 2017 tentang Izin Dan Penyelenggaraan Praktik Bidan tidak ada membahas tentang pemagangan bagi bidan yang sudah lulus dari pendidikan Diploma III dan IV. Kemudian dalam Peraturan Bupati Jembrana Nomor 40 Tahun 2016 tentang Kedudukan, Susunan Organisasi, Tugas Dan Fungsi, Serta Tata Kerja Dinas Kesehatan tidak ada pernyataan yang menyatakan bahwa Kepala Dinas Kesehatan Jembrana memiliki kewenangan untuk mengangkat bidan magang. Sehingga kedudukan atau status bidan magang di Kebupaten Jembrana tidak jelas. Maka untuk selanjutnya bidan magang juga tidak memiliki perlindungan hukum yang pasti di depan hukum apabila terjadi kesalahan yang berkaitan dengan pekerjaannya.

2. Pelaksanaan Tugas Dan Kewenangan Bidan Magang Sebagai Tenaga Kesehatan Dalam Memberikan Pelayanan Kesehatan Di Puskesmas II Melaya, Jembrana, Bali

Pemagangan bidan di Kabupaten Jembrana secara resmi dilakukan sejak tahun 2011 dan masih berlangsung hingga saat ini tahun 2018 sebanyak 56 bidan yang tersebar di 8 puskesmas wilayah Kabupaten Jembrana. Saat ini bidan magang di Puskesmas II Melaya sebanyak 8 orang. Bidan yang telah lulus pendidikan Diploma III dan Diploma IV serta telah memiliki STRB terlebih dahulu memasukkan surat lamaran pekerjaan ke Dinas Kesehatan Kabupaten Jembrana, kemudian Dinas Kesehatan berkoordinasi dengan puskesmas yang membutuhkan bidan magang. Apabila puskesmas tersebut membutuhkan bidan magang dan bidan yang bersangkutan bersedia ditempatkan di 
puseksmas tersebut, maka bidan menandatangi Surat Perjanjian Magang dengan materai 6000.

Isi dari Surat Perjanjian Magang tersebut diantaranya menyatakan bahwa bidan magang bersedia tidak mendapat gaji dan tidak menuntut pengangkatan Calon Pegawai Negeri Sipil (CPNS) ataupun tenaga Kontrak. Berdasarkan isi dari Surat Perjanjian Magang yang dikeluarkan oleh Dinas Kesehatan Kabupaten Jembrana tersebut hanya menuliskan kewajiban dari bidan magang, namun tidak menyebutkan hak-hak dari bidan magang. Di sisi lain bidan magang juga tidak diberikan cuti hamil dan melahirkan oleh Dinas Kesehatan Jembrana. Namun Kepala Puskesmas II Melaya membuat kebijakan yang mengizinkan bidan magang untuk istirahat selama 3-7 hari setelah melahirkan, serta mengalokasikan Jasa Pelayanan puskesmas yang diberikan untuk bidan magang \pm Rp.300.000,- yang dibagikan setiap 3 bulan sekali.

Dalam menjalankan pekerjaannya, bidan magang diizinkan untuk melakukan pelayanan kebidanan seperti bidan pada umumnya karena bidan magang memiliki ijazah dan keterampilan yang sama dengan bidan senior. Akan tetapi bidan magang tidak diizinkan memegang program kerja puskesmas secara langsung. Dikarenakan bidan magang membantu pekerjaan yang seharusnya dilakukan oleh bidan PNS atau Kontrak, sehingga untuk memastikan bidan magang tidak melakukan kesalahan selama tindakan kepada pasien, maka bidan PNS atau Kontrak harus mendampingi bidan magang dalam melakukan pelayanan kesehatan.

3. Persoalan Hukum Yang Muncul Dalam Pelaksanaan Tugas Bidan Magang Sebagai Tenaga Kesehatan Dalam Memberikan Pelayanan Kesehatan

Dalam Pasal 8 Peraturan Bupati Jembrana Nomor 40 Tahun 2016 tentang Kedudukan, Susunan Organisasi, Tugas Dan Fungsi, Serta Tata Kerja Dinas Kesehatan tidak terdapat poin yang menyatakan bahwa Kepala Dinas Kesehatan dapat mengangkat bidan magang. Dengan kata lain Bupati Jembrana selaku kepala daerah yang mempunyai kewenangan atributif tidak memberikan kewenangan delegatif kepada Kepala Dinas Kesehatan untuk mengangkat bidan magang. Selain itu di dalam Undang-Undang Nomor 36 Tahun 2009 tentang Kesehatan, Undang-undang Nomor 36 Tahun 2014 tentang Tenaga Kesehatan, Peraturan Menteri Kesehatan Nomor 28 Tahun 2017 tentang Izin Dan Penyelenggaraan Praktik Bidan, serta Rancangan Undang-Undang tentang Kebidanan (Midwifery) tidak ada yang menjelaskan tentang pemagangan untuk seorang bidan yang sudah lulus.

Kemudian Pasal 1320 Kitab Undang-Undang Hukum Perdata yang menjelaskan tentang syarat sahnya suatu perjanjian, maka Kepala Dinas Kesehatan Jembrana tidak memiliki kecakapan untuk melakukan perbuatan hukum yaitu membuat Surat Perjanjian Magang karena tidak memiliki kewenangan delegatif dari Bupati Jembrana. Serta pembuatan Surat Perjanjian Magang bertentangan dengan Undang-Undang, ketertiban umum, atau kesusilaan. Karena melanggar syarat obyektif sahnya perjanjian sebagaimana yang diatur dalam Pasal 1320 Kitab Undang-Undang Hukum Perdata, sehingga perjanjian tersebut batal demi hukum (null and void) atau perjanjian yang sejak semula sudah batal.

Dalam Pasal 57 Undang-Undang Republik Indonesia Nomor 36 Tahun 2014 tentang Tenaga Kesehatan dan Pasal 29 Peraturan Menteri Kesehatan Republik Indonesia Nomor 28 Tahun 2017 tentang Izin Dan Penyelenggaraan Praktik Bidan menyatakan bahwa bidan memiliki beberapa hak yang harus dipenuhi yaitu hak untuk memperoleh 
perlindungan hukum dan mendapat imbalan jasa. Kemudian Pasal 3 Ayat (2) dan Pasal 38 Ayat (3) Undang-Undang Nomor 39 Tahun 1999 tentang Hak Asasi Manusia menyatakan bahwa setiap orang berhak untuk memperoleh perlindungan hukum yang sama di depan hukum, dan mendapat upah selama melakukan pekerjaannya. Namun dalam Surat Perjanjian Magang hanya menyebutkan kewajiban bidan magang dan mengeliminasi hak-hak yang harus didapat seperti hak memperoleh perlindungan hukum dan menerima imbalan jasa.

Jadi konten Surat Perjanjian Magang tersebut melanggar HAM bagi tenaga kesehatan bidan, sebab bidan tidak mendapatkan haknya sesuai Pasal 3 Ayat (2) dan Pasal 38 Ayat (3) Undang-Undang Nomor 39 Tahun 1999 tentang Hak Asasi Manusia. Sehingga konten Surat Perjanjian Magang tersebut cacat hukum karena melanggar HAM bagi bidan. Serta Kepala Dinas Kesehatan menyalahi aturan sebab tidak memiliki kewenangan membuat perjanjian, menandatangani perjanjian, dan mengangkat tenaga bidan magang. Serta tidak memberikan hak-hak yang harus diperoleh bidan.

Supaya bidan magang di Kabupaten Jembrana memiliki kedudukan hukum, maka untuk kedepannya Bupati Jembrana perlu membentuk peraturan pelimpahan kewenangan Delegatif atau Mandat kepada Dinas Kesehatan. Pemberian pelimpahan kewenangan Delegatif atau Mandat kepada Dinas Kesehatan dengan pertimbangan bahwa puskesmas di Kabupaten Jembrana membutuhkan bidan magang. Selain itu untuk mempercepat proses penempatan bidan magang dikarenakan Dinas Kesehatan sebagai perangkat daerah yang mengetahui pemetaan bidan magang di Kabupaten Jembrana. Dengan alur yaitu puskesmas di Kabupaten Jembrana memberikan usulan kepada Dinas Kesehatan untuk mengangkat bidan magang.

Bentuk peraturan pelimpahan kewenangan Delegatif atau Mandat bisa berupa Keputusan Bupati atau Peraturan Bupati yang menetapkan tentang Mekanisme Dan Isi beserta bentuk pengangkatannya berupa Perjanjian yang memuat hak-hak bidan magang. Mekanisme Dan Isi dalam Keputusan Bupati atau Peraturan Bupati tersebut harus ada pembatasan waktu berapa lama pemagangan bidan untuk menghindari eksploitasi terhadap bidan magang karena tidak dipenuhinya hak bidan magang, serta bidan magang yang melakukan pemagangan terus-menerus di Kabupaten Jembrana tanpa diberikan imbalan jasa dan tidak memperoleh perlindungan hukum. Maka dari itu, dengan dasar pertimbangan bahwa kualifikasi minimal pendidikan bidan adalah Diploma III Kebidanan selama 3 tahun, maka pemagangan bidan dalam rentang waktu tersebut yaitu 1 tahun atau maksimal 2 tahun dan tidak perlu diperpanjang.

Selanjutnya untuk bentuk pengangkatan yang dimaksud bisa berupa Surat Keputusan (SK) Pengangkatan ataupun Perjanjian. Bentuk pengangkatan berupa SK Pengangkatan diperuntukkan bagi PNS, namun bentuk pengangkatan berupa Perjanjian digunakan untuk pegawai tidak tetap atau non PNS yaitu PPPK. Karena bidan magang bukanlah PNS, maka bentuk pengangkatan yang sesuai dengan kondisi tersebut ialah disamakan dengan PPPK yaitu Perjanjian yang memuat hak-hak bidan magang. Dengan adanya peraturan pelimpahan kewenangan Delegatif atau Mandat berupa Keputusan Bupati atau Peraturan Bupati yang menetapkan tentang Mekanisme Dan Isi beserta bentuk pengangkatannya berupa Perjanjian yang memuat hak-hak bidan magang, sehingga bidan magang di Kabupaten Jembrana memiliki kedudukan hukum di muka hukum. 


\section{SARAN}

1. Bupati Jembrana perlu membentuk peraturan pelimpahan kewenangan Delegatif kepada Dinas Kesehatan Jembrana berupa Keputusan Bupati atau Peraturan Bupati yang menetapkan tentang Mekanisme Dan Isi beserta bentuk pengangkatannya berupa Perjanjian yang memuat hak-hak bidan magang supaya tidak terjadi eksploitasi terhadap bidan magang.

2. Perlu adanya pembatasan waktu pemagangan dan pemenuhan hak bidan magang di dalam mekanisme pengangkatan bidan magang di Keputusan Bupati atau Peraturan Bupati.

\section{DAFTAR PUSTAKA}

Ali, Zainudin, 2016, Metode Penelitian Hukum, Jakarta: Sinar Grafika

Ashshofa, Burhan, 2004, Metode Penelitian Hukum, Jakarta: Rineka Cipta

Brannen, Julia, 2004, Memadu Metode Penelitian Kualitatif \& Kuantitatif, Yogyakarta: Pustaka Pelajar

Marmi, 2014, Etika Profesi Bidan, Yogyakarta: Pustaka Pelajar

M, Marwan, dan Jimmy. P, 2009, Kamus Hukum: Dictionary Of Law Complete Edition, Jakarta: Reality Publisher

Purwoastuti, Endang, dan Elisabeth Siwi Walyani, 2014, Konsep Kebidanan, Yogyakarta: Pustaka Baru Press

\section{Pustaka Baru Press}

2015, Mutu Pelayanan Kesehatan \& Kebidanan, Yogyakarta:

Raco, J. R, 2010, Metode Penelitian Kualitatif Jenis, Karakter Dan Keunggulannya, Jakarta: PT Gramedia Widiasarana Indonesia

Sugiyono, 2011, Statistika Untuk Penelitian, Bandung: Alfabeta

\section{Internet:}

Petunjuk Praktis Magang Di Rumah Sakit Bagi Staff Puskesmas, hal. 5, Online Internet, 24 September 2018, Pukul $\quad 19.55 \quad$ WIB, https://www.scribd.com/document/361192696/magang

\section{Wawancara:}

dr. Putu Suasta, M.Kes, Kepala Dinas Kesehatan Kabupaten Jembrana, Wawancara Tanggal 12 Februari 2018

dr. Riadi Wiranuaba, Kepala Puskesmas II Melaya, Wawancara Tanggal 19 Februari 2018

Drs. I Made Budiasa, M.Si, Kepala Badan Kepegawaian Dan Pengembangan Sumber Daya Manusia (BKPSDM) Kabupaten Jembrana, Wawancara Tanggal 13 Februari 2018

Galuh Pramita, Amd.Keb, Bidan Magang Puskesmas II Melaya, Wawancara Tanggal 19 Februari 2018 
Ni Ketut Sutami, Bidan PNS Puskesmas II Melaya, Wawancara Tanggal 19 Februari 2018

Ni Ketut Warsini, SKM, Ketua IBI Cabang Kabupaten Jembrana, Wawancara Tanggal 12 Februari 2018

Yovita Indrayati, S.H., M.Hum, Ahli Hukum Universitas Katolik Soegijapranata Semarang, Wawancara Tanggal 28 September 2018

\section{Perundang-Undangan:}

Kitab Undang-Undang Hukum Perdata

Undang-Undang Nomor 39 Tahun 1999 tentang Hak Asasi Manusia

Undang-Undang Nomor 39 Tahun 1999 tentang Hak Asasi Manusia

Peraturan Menteri Kesehatan Republik Indonesia Nomor 28 Tahun 2017 tentang Izin Dan Penyelenggaraan Praktik Bidan

Peraturan Menteri Tenaga Kerja Dan Transmigrasi Republik Indonesia Nomor PER.22/MEN/IX/2009 tentang Penyelenggaraan Pemagangan Di Dalam Negeri

Surat Perjanjian Magang Nomor 800/003/MGG/Diskes/2017 